Article

\title{
Critical Success Factors, Motivations, and Risks in Social Impact Bonds
}

\author{
Rosella Carè $^{1, * \mathbb{C}}$, Francesco Rania ${ }^{2} \mathbb{C}$ and Riccardo De Lisa ${ }^{1}$ \\ 1 Department of Economics and Business, University of Cagliari, 09124 Cagliari, Italy; delisa@unica.it \\ 2 Department of Law, Economics and Sociology, University Magna Graecia of Catanzaro, \\ 88100 Catanzaro, Italy; raniaf@unicz.it \\ * Correspondence: rosella.care@unica.it
}

Received: 7 July 2020; Accepted: 25 August 2020; Published: 5 September 2020

\begin{abstract}
Social impact bonds (SIBs) have emerged as one of the most innovative financial instruments designed to support the social service sector in the delivery of innovative social programs. Despite the growing interest of academics and practitioners in SIBs, the debate appears polarized around a series of recurrent aspects, and only a limited number of studies have sought to understand the risks and motivations related to similar initiatives. Using an exploratory approach based on a mixed-method grounded theory methodology, this study analyzed the results of 12 questionnaires that asked experts about their experiences and perceptions in SIB project development and implementation. The study identified and assessed three main groups of motivations, critical success factors, and risk factors by focusing on the private-sector SIB actors with the aim of understanding their motivations and their perceived main success drivers and risk factors. This work contributes to the knowledge on the conditions for attracting private sector actors and supporting policymakers in the development of new SIB models. The findings could facilitate the development of risk management practices for the purpose of stimulating the participation of private actors in SIB initiatives.
\end{abstract}

Keywords: social impact bonds; payment by results; impact investing; grounded theory

\section{Introduction}

Social impact bonds (SIBs) have emerged as one of the most innovative financial instruments aimed at capturing new needs in the social service sector by boosting innovation and quality [1]. Conceived as a cross-sector collaboration model designed to fund social programs by creating a shared vision between the public and private sectors [2,3], SIBs are a mechanism for leveraging private investment in social interventions through "optimal" risk-sharing and innovative design in the delivery of public services by the private sector $[1,4,5]$.

From a contractual point of view, SIBs differ from payment by results $(\mathrm{PbR})$ contracts in the participation of investors who provide the working capital for the implementation of programs by receiving a return depending on the achievement of the established outcomes [6,7]. The SIB begins when the commissioner (usually a public administration at the national or local level) identifies a certain social issue and target population and decides to enter into a contract with a financial or social finance intermediary that usually arranges the scheme. After receiving the working capital required for the implementation of the program, the service provider (usually social enterprises that play a pivotal role in providing solutions to social problems) delivers the scheduled intervention. The outcome measurement represents one of the central elements in SIBs: after the independent assessment/evaluation, and only in the case of achievement of predefined outcome levels, the commissioner provides payments $[7,8]$. To date, there are estimated to be more than 130 SIBs already operating and more than 60 SIBs 
under development in 34 countries distributed around several social issues (e.g., criminal justice, homelessness, health and wellbeing issues, workforce development) [9].

Despite the growing interest of academics and practitioners in SIBs, much remains to be learned. The debate appears polarized around a series of recurrent aspects [10], and only a limited number of studies have sought to understand the risks and motivations $[7,8,11-14]$ related to similar initiatives.

Given these considerations, this study aimed to understand the main motivations (MOs), critical success factors (CSFs), and risks (RIs) in SIB projects. Using an exploratory approach based on a mixed-method grounded theory methodology, this study analyzed the results of 12 questionnaires asking experts about their experiences and perceptions in SIB project development and implementation - thereby addressing calls for more research in this field [7]. Increased knowledge of the main motivations (MOs), critical success factors (CSFs), and risks (RIs) in the SIB context can facilitate our understanding of how they can be addressed during both the design and implementation stages, identify possible sources of project failure, and even provide guidance for how appropriate guidelines and risk management processes might be developed. Finally, the findings could support the development of risk management practices to stimulate the participation of private actors in SIB initiatives. The following sections clarify the context of the research. In particular, the "Research Design" section discusses the methodology, while the "Results and Discussion" section examines the answers to the questionnaire and the results of the analysis. Finally, the "Conclusions, Implications, and Future Research Directions" section summarizes the main findings and provides a brief discussion of the practical implications of the study by providing suggestions for further research.

\section{Theoretical Background}

The academic research on SIBs has rapidly grown. The following sections examine various aspects related to SIBs by providing the basis for the development of literature-based lists of MOs, CSFs, and RIs.

\subsection{SIB Architecture and the Role of Different Actors' Interests}

The SIB approach was first proposed in the United Kingdom (through the HMP Peterborough SIB) in 2010, and it has quickly spread internationally and across different sectors [15]. Built around a collaborative public-private contract, SIBs represent a new funding model that aims to improve service quality and to enhance the social outcomes achieved by using private resources rather than public funding. Under the SIB approach, the public sector pays for the achievement of outcomes and results that provide a reasonable cost-saving to the taxpayer by transferring the risk of financial losses in cases of ineffective/inefficient projects from the public to the private sector [16]. Advocates of SIBs suggest that these new schemes have the capacity to leverage additional resources for innovative services designed to provide, in the future, improved social outcomes and cost savings for public commissioners [17].

The academic literature around SIBs includes two major trends: the first depicts SIBs as a full "win-win model"; the second, following a more "cautionary approach" [5,18], focuses on criticism of the marketization of the delivery of traditionally public services, the ability to effectively provide better outcomes, the value provided by such approaches compared to their cost structure and the additional transaction and administrative costs they generate $[5,10,16,17,19,20]$.

Considered an evolution of public-private partnership (PPP) and designed around a series of contracts in the commissioning and provisioning of social services, SIBs are developed in the form of a principal-multiagent relationship [21]. The combination of the different actors involved in an SIB project (Figure 1) enables the public commissioner to provide innovative services by sharing the risk of exploring a new welfare approach with private investors who provide the working capital for social projects by receiving both a financial and a social return $[8,21]$. The main actors and the typical contractual model of an SIB scheme are summarized in Figure 1. 


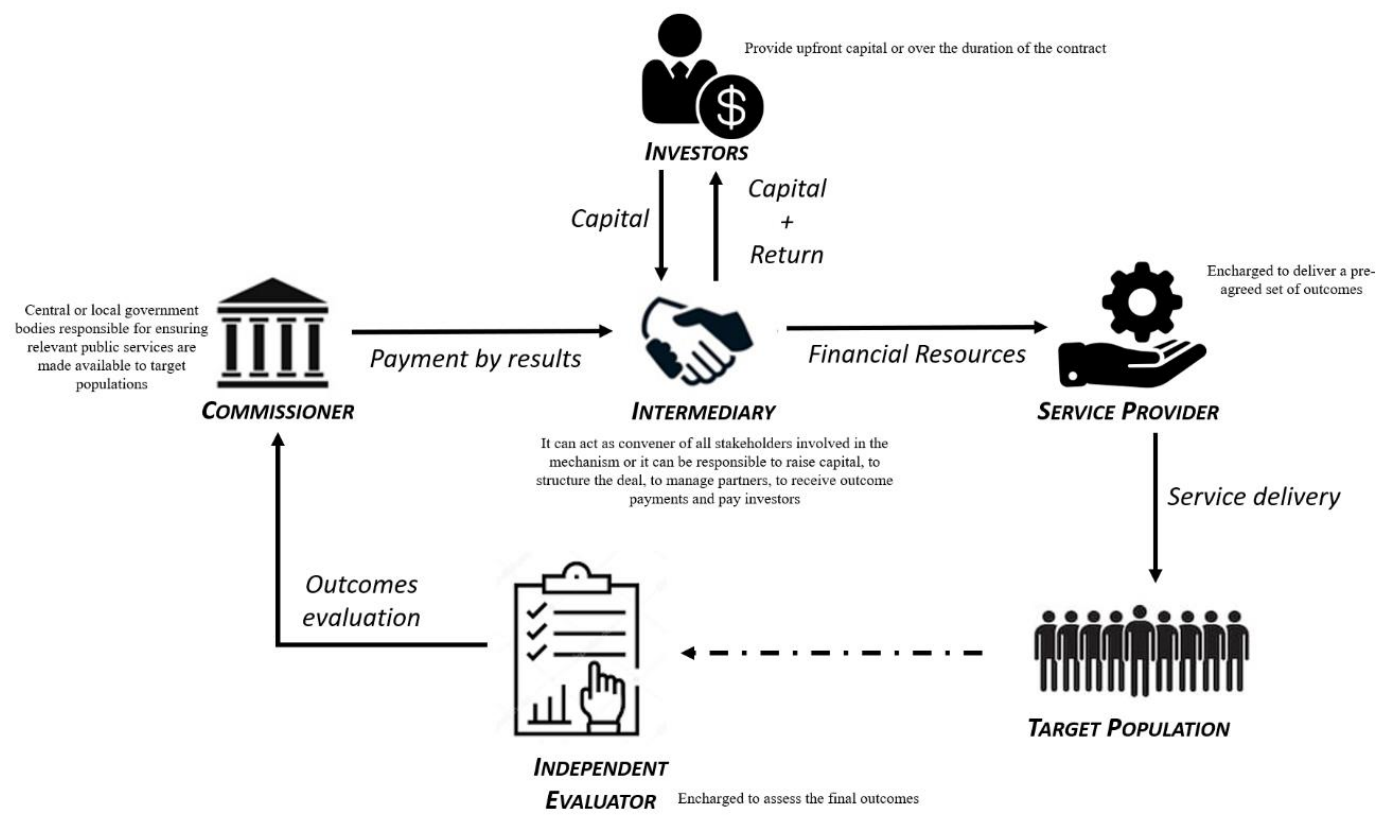

Figure 1. The SIB structure and the involved actors. (Source: own elaboration).

In addition to the main actors identified in Figure 1, depending on the structure of the SIB, further actors may participate in the deal, such as subordinate investors, guarantors, or legal/technical advisors [2].

\subsection{Review of Motivations for Implementing SIB Projects}

One of the stated strengths of SIBs is that they bring to the project a multitude of stakeholders, each with different motivations for participating [22].

In the SIB model, all actors pursue their social motivations and align their expectations and motivations to achieve social outcomes that can generate enough cost savings to provide a return on investment for the investors [12].

There are many private-sector motivations for supporting SIBs, only some of which may be altruistic [23].

SIBs were conceived as a form of financial innovation within the broader sphere of impact investing. Under this perspective, impact investors have a myriad of motivations that are often related to the need to make investments that align with their values, particularly values that prioritize societal change and the creation of social good [11]. Thus, investors are attracted to SIBs for the same reasons as those that attract them to any impact investment: social and financial returns. However, as clarified by Goodall [24], within the impact investing landscape, SIBs offer the opportunity to invest in entrepreneurial solutions that investors may not be able to address with the rest of their impact investment portfolio.

Institutional investors are also partly motivated by the opportunity to finance entrepreneurial solutions that they have historically been unable to support [24]. At the same time, foundations that invest in SIBs span from those motivated by the opportunity to make program-related investments, which allow them to earn back their money and recycle funding into another grant or venture/investment, to those that are comfortable making a nonrecoverable investment [24]. Foundations or other organizations that provide grants (as part of their CSR strategies) view SIBs as an opportunity to "recycle grants" after the end of the project [22] and as an opportunity to gain a reputational return. Service providers (usually social enterprises) are motivated to join an SIB because it provides them with a stable, long-term revenue stream, allowing them to achieve outcomes, encouraging innovation and creativity, and letting them focus only "on doing what they do best" [22,24]. 
However, from the public perspective, the commissioner (the outcome funder) is often motivated to enter into an SIB by the monetizable savings in social services provisions, by the reduction in risk if the service is not successful, and by the benefit and cost savings for society in the long run if the outcomes are successful [22,24].

Finally, publicity and visibility should not be underestimated as motivations for participating in SIBs [22].

\subsection{Critical Success Factors in SIB Projects}

Academics and practitioners have widely recognized certain key aspects that should be considered for the implementation of SIB projects. In this vein, for example, Carè and De Lisa [2] highlighted the role of robust contractual schemes in creating "certainty where possible, and bounded flexibility where needed, thereby retaining clarity and limiting uncertainty for both parties" (p. 16).

From a theoretical point of view, a well-structured SIB creates an incentive structure that aligns the interests of all involved parties [25]. The concept of "aligned interest" refers to agency theory, which has traditionally been employed to explain issues in the relationship between principals and agents. The issue of agency problems has been explored by several authors $[13,25,26]$. Agency distortions can include selecting clients with high-performance probability rather than clients with a lower probability to hit target thresholds [17]. Even if interest alignment in an SIB is substantially stronger than with other forms of contracting, due to their outcome-based incentives, public-private contracts also face the contractual hazards of governmental opportunism and third-party opportunism under the presence of standard opportunistic behavior, such as moral hazard and adverse selection [13]. As clarified by Balboa [26], in each of the steps of SIB project implementation, a different actor may take the lead in advancing the contract, triggering different accountability goals reflecting public and private actors' normative priorities. Moreover, from a governance perspective, the absence of a direct relationship between the service provider and the public commissioner potentially generate information asymmetries [2].

In addition to the robustness of the contractual schemes, other facilitating factors in SIB development are government/institutional support, the credibility and capacity of the intermediary, and the availability of technical/legal advice, mainly because these actors can help navigate the complex deal implementation process [2,27].

\subsection{Risks Affecting SIB Projects: An Overview}

The academic literature that has explored risks in this field of research can be classified into two main areas. The first strand of research considers SIBs under a portfolio perspective and thus, by positioning these assets in the broader sphere of impact investments. Under this perspective, typical risks include financial risk-for investors in terms of losing their return and capital [12]. In the same vein, Emerson et al. [28] clarified that impact investors are generally concerned with traditional risks (including financial risk, enterprise risk, and market risk) and with various aspects of risks more typical to the context of impact investing (such as liquidity risk, impact risk, measurement and reporting, exit risk, thematic area risk, asset class risk, subordinate capital risk, manager risk, fund development risk, and social enterprise risk).

In contrast, the second strand of research underscores that this category of assets-which is more like PPP projects—can also be exposed to other kinds of risk. In this sense, coordination risk, funding risk, implementation and impact risk, measurement and pricing risk, government counterparty, and reputational risk may arise, which collectively have an impact on the financial and social risks to the stakeholders of an SIB project [29]. Carè [8] provided a classification of risks into three main levels: (1) the macrolevel grouping risks that typically occur beyond the boundaries of the project, including political and policy risks; (2) the microlevel, which groups risks related to the relationship between the involved parties, including the partnership risk; and (3) the mesolevel, which includes risks occurring within the boundaries of the project, including the programmatic (the risk that the 
program does not work), operational (that may occur when the program is not executed as scheduled in the design phase), and evaluation risks. Risks may also arise from changes in legislation or policies (regulatory or policy risk), from the actors such that the actors involved in the deal do not fulfill their contractual obligations (partnership risk), or project underperformance (performance risk) [30].

Another risk that may affect an SIB scheme is related to the program's ability to generate a positive impact and to be correctly implemented, which several authors identify as impact risk $[7,29,31]$. Moreover, risks might arise from the short track record of performance (early-stage of the market) or from the absence of policy support and measurement systems (ecosystem risk) [32]. Table 1 provides an overview of the main risk categories retrieved.

Table 1. Overview of the main risks.

\begin{tabular}{|c|c|c|}
\hline Category of Risk & Main Definition & Main references \\
\hline Execution risk & $\begin{array}{c}\text { "Execution risk concerns the feasibility of the project and initial design of the social } \\
\text { project, which requires clear pilot data with a well-documented history of social } \\
\text { interventions" (Schinckus, 2017, p. 4). }\end{array}$ & {$[14,33]$} \\
\hline Financial risk & $\begin{array}{l}\text { "the financial risk is about the contingent conditions of repayment to investors: in } \\
\text { accordance with the agreement, the issuing authorities must ensure they have } \\
\text { sufficient funds in hand to meet financial obligations in case of success" } \\
\text { (Schinckus, 2017, p. 4). }\end{array}$ & [33] \\
\hline Intermediary risk & $\begin{array}{l}\text { "the risk that the SIB intermediary will fail to perform its obligations, which in } \\
\text { turn would frustrate the achievement of the SIB's social and financial goals" } \\
\text { (Burand, 2013, p. 472) }\end{array}$ & {$[14,33]$} \\
\hline Operational risk & $\begin{array}{c}\text { "Operational risks may occur when the program is not executed as scheduled in the } \\
\text { design phase" (Carè, 2019, p. 161) }\end{array}$ & {$[6,8,30,34]$} \\
\hline Political risk & $\begin{array}{l}\text { "political risk relates to both the capacity and the will of the host government to } \\
\text { undertake its obligations under a SIB structure and, equally importantly, not to } \\
\text { hinder others from meeting their respective SIB obligations. This political risk can } \\
\text { manifest itself in many ways, including interference with SIB measurement tools, } \\
\text { forced renegotiation of SIB contractual terms, manufactured delays (or the creation } \\
\text { of other obstacles) to passing appropriate authorizing legislation to permit the } \\
\text { government to meet its SIB obligations, or even nonpayment of SIB obligations" } \\
\text { (Burand, 2013, p. 473) }\end{array}$ & {$[14,33]$} \\
\hline Reputational risk & $\begin{array}{l}\text { "All players in a SIB structure are vulnerable to reputation risk should the SIB } \\
\text { transaction not succeed. Social service providers are perhaps at the front line of } \\
\text { reputational risk since their failure to meet targeted outcomes could have } \\
\text { far-reaching implications beyond just the SIB structure. Yet other SIB parties may } \\
\text { suffer reputational risk too should a SIB fail" (Burand, 2013, p. 480). }\end{array}$ & {$[6,29,33,35]$} \\
\hline Impact/social risk & $\begin{array}{l}\text { "the term social risk is used to identify the possibility that the expected social } \\
\text { outcome is not achieved" (Scognamiglio et al., 2018, p. 18). }\end{array}$ & {$[6,7,14,32]$} \\
\hline Programmatic risk & "Risk that the program does not work" (Tekolste et al., 2016, p. 8). & {$[6,8,34]$} \\
\hline \multirow{2}{*}{ Intervention model risk } & $\begin{array}{l}\text { "Intervention model risk refers to the risk that the chosen social service } \\
\text { interventions do not produce the expected outcomes" (Burand, 2013, p. 468). }\end{array}$ & \multirow[t]{2}{*}[33,36]{} \\
\hline & $\begin{array}{c}\text { "Risk that the program does not work. This risk decreases as evidence of program } \\
\text { effectiveness increases" (GPRBA, 2019, p. 12). }\end{array}$ & \\
\hline Evaluation risk & $\begin{array}{c}\text { "Risk that the program's evaluation fails to accurately measure whether outcomes } \\
\text { have been achieved (e.g., a false positive or negative). This could be caused by poor } \\
\text { evaluation design or implementation" (Tekolste et al., 2016, p. 3). }\end{array}$ & {$[6,8,14,34]$} \\
\hline Regulatory or policy risk & $\begin{array}{l}\text { "Risk that new legislation or policies will change the composition of the target } \\
\text { population or otherwise undermine service delivery" (Tekolste et al., 2016). }\end{array}$ & {$[30,34]$} \\
\hline Partnership risk & $\begin{array}{l}\text { "Risk that the project will end before its scheduled date because one or more actors } \\
\text { in the deal do not fulfill contractual obligations" (Tekolste et al., 2016, p. 3). }\end{array}$ & {$[30,34]$} \\
\hline Performance risk & $\begin{array}{l}\text { "Any risk that could cause a project to underperform and fall short of its outcome } \\
\text { targets, implying loss of principal" (Tekolste et al., 2016, p. 2). }\end{array}$ & {$[17,30,33,37-40]$} \\
\hline \multirow[t]{2}{*}{$\begin{array}{l}\text { Appropriation, credit or } \\
\text { counterparty risk }\end{array}$} & $\begin{array}{c}\text { "Appropriations risk, also called credit or counterparty risk, is the potential that } \\
\text { the end payer (typically a government) will not repay the investor if the project } \\
\text { meets its outcome targets"(Tekolste et al., 2016, p. 8). }\end{array}$ & \multirow[t]{2}{*}[30,36]{} \\
\hline & $\begin{array}{l}\text { "Risk that the end payer (typically a government) will not repay the investor if the } \\
\text { project meets its outcome targets" (GPRBA, 2019, p. 12). }\end{array}$ & \\
\hline Liquidity risk & $\begin{array}{l}\text { "Liquidity risk can be defined as the risk investors face when funding a SIB contract } \\
\text { whose payouts occur over an extended time span" (Bergfeld et al., 2019, p. 21). }\end{array}$ & {$[6,28,41]$} \\
\hline Macroeconomic risks & $\begin{array}{c}\text { "Risks that result from the adverse movement in key macroeconomic indicators, } \\
\text { such as inflation, exchange rates, and interest rates that impact the ability of the } \\
\text { project to operate at normal parameters and generate the cash flows needed to pay } \\
\text { the investors and lenders". (GPRBA, 2019, p. 12). }\end{array}$ & [36] \\
\hline
\end{tabular}




\section{Research Design}

This study aims to explore MOs, CSFs, and RIs in SIB projects. An exploratory study is an appropriate approach "when not much is known about the situation at hand, or no information is available on how similar problems have been solved in the past" [42], (p. 103). The current study used an exploratory approach based on a mixed-method grounded theory methodology. The grounded theory methodology is a methodological approach for developing theory that is grounded in data $[43,44]$ and in which data collection, analysis, and theory stand in a "reciprocal relationship to one another" [44]. Mixed-method design explicitly aims to offer a framework for combining methods being conceived as a form of research that employs a systematic integration-or mixing —of different quantitative and/or qualitative methods, which combine with and supplement each other within a single project $[45,46]$. For the purpose of this study, both secondary (from the literature review) and primary data (collected through the survey questionnaire) were used to move the emerging theory forward and to allow for triangulation, which was employed to reduce the chances of reaching false conclusions.

In greater detail, because of the paucity of existing knowledge about the topic under investigation, a six-step process was followed (Figure 2).

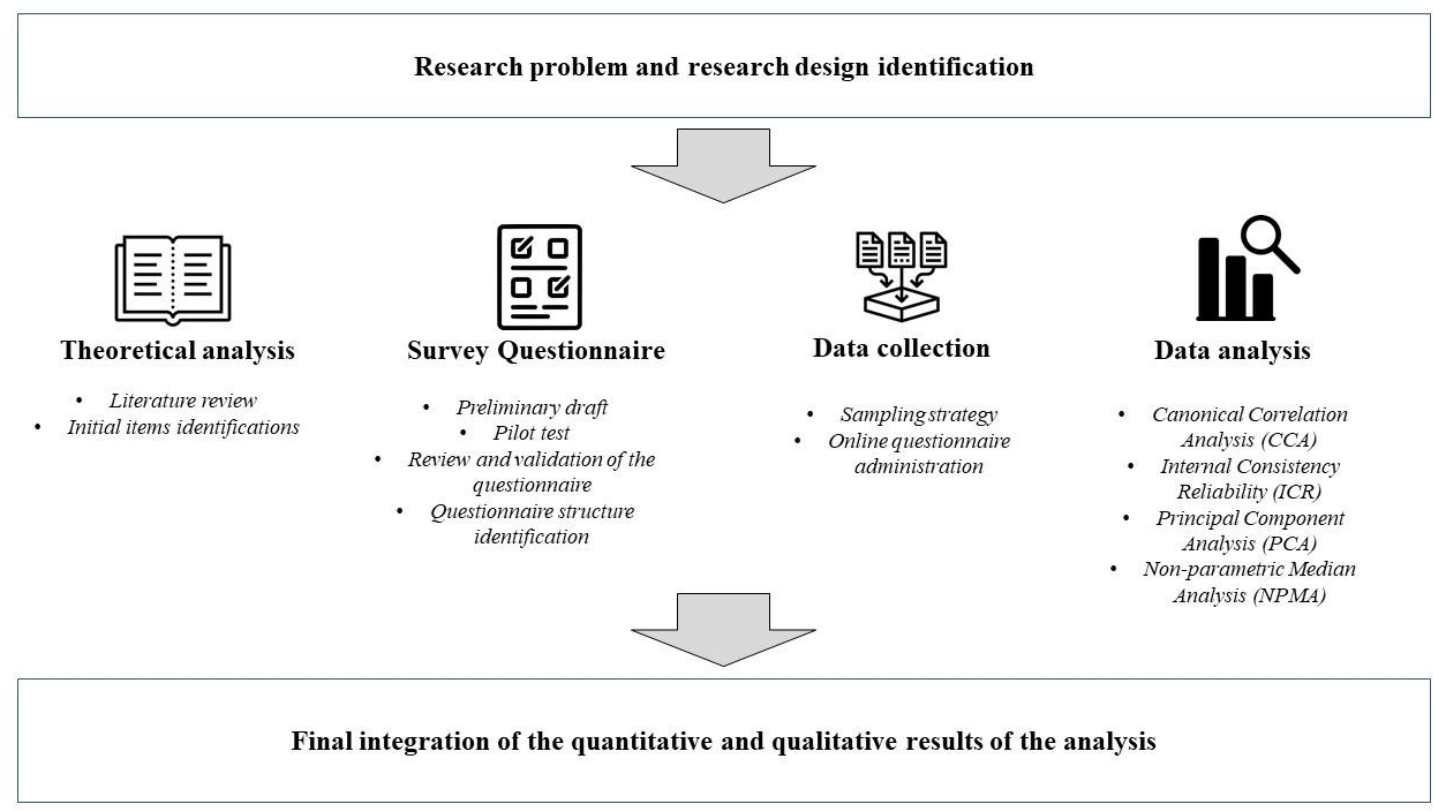

Figure 2. Research design. (Source: own elaboration)

First, starting from the literature review, a comprehensive list of MOs, CSFs, and RIs was developed. Considering the uniqueness of SIB projects and the fact that no previous lists have been developed in other works, an expert's thinking was adopted to revise and improve the reliability of the lists.

Two researchers - with different expertise in risk management and SIBs—-built their initial lists independently and then discussed the discrepancies. Categories were decided on and created by the two researchers together. Based on the initial items established, the two researchers revised their own lists again. In addition, new items were generated by each researcher. The final lists were obtained after the $100 \%$ agreement was reached by the two researchers.

Then, the lists of MOs, CSFs, and RIs were sent to three international scholars with expertise on SIBs, risk management, and finance to check for clarity and completeness. This pilot study was previously conducted to confirm the initial lists, to test the questions and/or their sequences and to estimate the time used to complete the questionnaire [42,47]. The three experts were involved in a double round revision of the questionnaire that was subsequently modified in accordance with their observations before sending it to the sample. 
Initially, a total of 82 items were identified: 23 (28.05\%) on MOs, $16(19.52 \%)$ on CSFs, and 43 (52.44\%) on RIs.

A Google Drive questionnaire was prepared with the final items. The participants were contacted via e-mail, and a cover letter explained the survey's purpose, the privacy conditions on the data diffusion, and the time, which was fixed (two weeks) from the reception, to return the questionnaire.

The questionnaire was necessarily structured as a multiple-choice type and divided into four sections. Section A was devoted to the collection of the respondents' background information with eight items (on organization, qualification, types, and number of SIB projects made). Sections B, C, and D investigated MOs, CSFs, and RIs, respectively. The items of B, C, and D were measured on a five-point Likert scale, with $5=$ very important being the highest and $1=$ not all important being the lowest rating.

The sample was composed using a stratified approach to represent both the existent geographical distribution and the composition in various subgroups (Saunders, 2009). At the end of August 2019, 30 organizations working on SIB projects were randomly chosen based on "geographical area" and "type of organization". With regard to the sample size, for a $95 \%$ confidence level, assuming a population of 400 potential participants in the SIB projects, and $p=0.95,30$ respondents guaranteed a minimum error of $7.5 \%$ on the reliability of results and thus, a good level of reliability for a pilot test. A questionnaire was considered valid if it contained no more than 5 out of 89 unanswered items, and the total score was within the central $95 \%$ range. After one month, 12 questionnaires were returned $(66.7 \%)$, and all of them passed the checks $(100.0 \%)$. The final sample was composed of private sector organizations operating in the United Kingdom (labeled as "UK") for 50.0\%, Australia (labeled "AUST") for 33.3\%, and other countries (labeled as "Others") for 16.7\%. The organizations were categorized as advisor for $41.7 \%$, financial advisor for $25.0 \%$, investor for $16 \%$, and service provider or evaluator for $8.3 \%$. Table 2 provides an overview of the sample.

Table 2. Background information: respondents by type, role, and social issue.

\begin{tabular}{|c|c|c|c|c|c|}
\hline Country & Organization Profile & Respondent Role & Role Description & $\begin{array}{c}\text { Macro } \\
\text { Category }\end{array}$ & Issue \\
\hline AUS & $\begin{array}{l}\text { Not-for-profit organizations and } \\
\text { providers of community services }\end{array}$ & $\begin{array}{l}\text { Research and Social } \\
\text { Policy Program Head }\end{array}$ & Service delivery & $\begin{array}{l}\text { Service } \\
\text { provider }\end{array}$ & $\begin{array}{c}\text { Child and } \\
\text { family welfare }\end{array}$ \\
\hline AUS & Consulting company & Director & Legal advice & Advisor & Homeless \\
\hline AUS & Pension fund & $\begin{array}{l}\text { Manager } \\
\text { (Sustainable } \\
\text { Portfolios } \\
\text { Governance) }\end{array}$ & Investor & Investor & Other/multiple \\
\hline Other & Foundation & Director India & $\begin{array}{l}\text { Advice and support to initial } \\
\text { scoping and opportunity } \\
\text { identification }\end{array}$ & Advisor & $\begin{array}{l}\text { Education and } \\
\text { early years }\end{array}$ \\
\hline UK & Consulting company & Director & Feasibility study & Advisor & $\begin{array}{c}\text { Child and } \\
\text { family welfare }\end{array}$ \\
\hline UK & Charitable trust (publicly owned) & $\begin{array}{l}\text { Social Investment } \\
\text { Fund Manager }\end{array}$ & $\begin{array}{l}\text { Advice and support to initial } \\
\text { scoping and opportunity } \\
\text { identification }\end{array}$ & Advisor & $\begin{array}{l}\text { Child and } \\
\text { family welfare }\end{array}$ \\
\hline UK & $\begin{array}{l}\text { Investment management and } \\
\text { advisory firm }\end{array}$ & Head of Investments & Working capital funding & Investor & $\begin{array}{l}\text { Employment } \\
\text { and training }\end{array}$ \\
\hline UK & Consulting company & Executive Director & Feasibility studies & Advisor & $\begin{array}{l}\text { Employment } \\
\text { and training }\end{array}$ \\
\hline UK & Consulting company & Technical Director & Evaluation & Evaluator & Homeless \\
\hline Other & $\begin{array}{l}\text { Social ventures investment } \\
\text { company }\end{array}$ & Managing Director & $\begin{array}{c}\text { Commercial aspects of SIB } \\
\text { structure and SPV } \\
\text { development }\end{array}$ & $\begin{array}{l}\text { Investment/ } \\
\text { Financial } \\
\text { advisory }\end{array}$ & $\begin{array}{l}\text { Child and } \\
\text { family welfare }\end{array}$ \\
\hline
\end{tabular}




\section{Statistical Analyses}

Once the data were collected, the variables were identified and classified. All data from Section A were used, and the items were treated as nominal variables and described through their proportions. The data from Sections B, C, and D were processed with CCA to mark those that were highly linearly correlated. Then, 29 items of 82 were considered as categorical variables, that is, only those with non-significantly higher correlation were chosen. The selected items were distributed per area as follows: 11 in MOs, 9 in CSFs, and 9 in RIs. The 29 variables (or items) were described through the median and its relative confidence interval given by bootstrapping procedure (see columns 2-8 of Table 3).

Once variables were selected, the total and partial consistency of the 29-item questionnaire and its single sections were tested, respectively. In both cases, ICR obtained good results. The $\alpha$-Cronbach was approximately 0.821 (0.808 per 29 items, 0.807 per $11 \mathrm{MO}$ items, 0.811 per 9 CSF items, 0.856 per 9 RI items) and confirmed almost identical results when the items were deleted one at a time.

Successively, an exploratory principal component analysis (PCA) of the items of each focus area (MOs, CSFs, and RIs) was carried out with the aim of obtaining a possible factorization and to investigate latent variables in the data. PCA is a multivariate data analysis technique that can be used to recombine the variables of a large dataset in such a way that the first few variables of the reconstructed dataset account for most of the variance in the data. A Kaiser-Meier-Olkin test obtained sufficient $p$-values that were appropriate in the lack of correlation of the involved items $(0.600$ per $11 \mathrm{MO}$ items, 0.623 per 9 CSF items, 0.598 per 9 RI items). Each focus area could be aggregated into three components for a total of three distinct dimensions (initially labeled 1, 2, and 3). Moreover, the weight of each variable in any component and the final weight inside the area (see columns 9-12 of Table 3) were computed.

Finally, a one-sample Wilcoxon signed rank test and a Kruskal-Wallis test of nonparametric median analysis (NPMA) were used to verify the following hypotheses:

H1: The respondent will evaluate any aspect of an SIB project in an optimal way.

H2: The attitudes of the respondent versus the SIB project will not change based on variations in the geographical area and/or the type of organization.

To validate $\mathrm{H} 1$, each variable was tested for whether it was significantly near the value 3 on a scale from 1 to 5 . To validate $\mathrm{H} 2$, it was verified whether the subsamples obtained by splitting the original sample through "geographical area" and "type of organization" were drawn from the same distribution (see columns 13-15 of Table 3). 
Table 3. Statistics, IC, Weights, Hypothesizes.

\begin{tabular}{|c|c|c|c|c|c|c|c|c|c|c|c|c|c|c|}
\hline \multirow[t]{2}{*}{ Focus Area } & \multirow[t]{2}{*}{ Variable } & \multicolumn{4}{|c|}{ Statistic } & \multicolumn{2}{|c|}{$95 \%$ IC } & \multicolumn{4}{|c|}{ Weight } & \multirow{2}{*}{ Hypothesis 1} & \multicolumn{2}{|c|}{ Hypothesis 2} \\
\hline & & Obs. & Min. & $\operatorname{Max}$. & Median & Lower & Upper & Dim. 1 & Dim. 2 & Dim. 3 & Final & & Geo. Area & Type Organ \\
\hline \multirow{8}{*}{ MOs } & SIBs offer an interesting financial return & 12 & 1 & 5 & 3.50 & 2.50 & 4.00 & 0.371 & 0.001 & 0.001 & 0.108 & 0.584 & $0.025 * *$ & 0.307 \\
\hline & $\begin{array}{l}\text { Good track records and the prior experience of all } \\
\text { parties involved }\end{array}$ & 12 & 1 & 5 & 4.00 & 3.00 & 5.00 & 0.199 & 0.017 & 0.042 & 0.082 & $0.050^{* *}$ & 0.114 & 0.514 \\
\hline & $\begin{array}{l}\text { SIBs offer diversification opportunities in our } \\
\text { broader portfolio of investment/activities }\end{array}$ & 12 & 1 & 4 & 3.00 & 1.50 & 3.50 & 0.268 & 0.056 & 0.002 & 0.092 & 0.260 & 0.103 & 0.910 \\
\hline & Presence of tax relief mechanism & 12 & 1 & 4 & 2.00 & 1.00 & 3.00 & 0.004 & 0.405 & 0.023 & 0.105 & 0.026 ** & 0.975 & 0.514 \\
\hline & Reputational return & 12 & 1 & 4 & 2.50 & 1.00 & 3.50 & 0.031 & 0.162 & 0.019 & 0.055 & $0.100 *$ & 0.462 & 0.672 \\
\hline & $\begin{array}{l}\text { SIBs provide opportunities to enter into new } \\
\text { market sectors }\end{array}$ & 12 & 1 & 4 & 3.00 & 2.50 & 3.50 & 0.000 & 0.299 & 0.007 & 0.072 & 0.516 & 0.261 & 0.551 \\
\hline & $\begin{array}{l}\text { Opportunities of risk sharing between the different } \\
\text { involved parties }\end{array}$ & 12 & 2 & 5 & 4.00 & 3.00 & 4.00 & 0.027 & 0.023 & 0.172 & 0.096 & $0.052 *$ & 0.652 & 0.738 \\
\hline & We have engaged in similar initiatives before & 12 & 1 & 4 & 4.00 & 3.00 & 4.00 & 0.003 & 0.000 & 0.164 & 0.080 & 0.248 & 0.197 & 0.873 \\
\hline \multirow{12}{*}{ CSFs } & SIBs are a philanthropic opportunity & 12 & 1 & 4 & 2.50 & 1.50 & 3.00 & 0.063 & 0.029 & 0.156 & 0.100 & 0.046 ** & 0.228 & 0.811 \\
\hline & SIBs offer benefit to local communities & 12 & 1 & 5 & 4.00 & 3.01 & 5.00 & 0.002 & 0.001 & 0.216 & 0.105 & 0.143 & 0.879 & 0.584 \\
\hline & SIBs offer opportunities to help people in need & 12 & 1 & 5 & 4.50 & 3.01 & 5.00 & 0.032 & 0.008 & 0.196 & 0.106 & $0.039 * *$ & 0.831 & 0.261 \\
\hline & Efficient cooperation between the involved parties & 12 & 4 & 5 & 5.00 & 4.00 & 5.00 & 0.042 & 0.299 & 0.063 & 0.122 & $0.002 * * *$ & 0.855 & 0.722 \\
\hline & Responsibilities and duties are clearly allocated & 12 & 4 & 5 & 5.00 & 4.00 & 5.00 & 0.000 & 0.394 & 0.001 & 0.113 & $0.002 * * *$ & 0.730 & 0.332 \\
\hline & $\begin{array}{l}\text { Presence of feasible, credible, and clear social needs } \\
\text { identification and description }\end{array}$ & 12 & 2 & 5 & 5.00 & 4.00 & 5.00 & 0.039 & 0.066 & 0.305 & 0.125 & $0.004 * * *$ & 0.380 & 0.618 \\
\hline & Strong commitment of all involved parties & 12 & 4 & 5 & 5.00 & 4.50 & 5.00 & 0.038 & 0.044 & 0.278 & 0.110 & $0.001 * * *$ & 0.361 & 0.258 \\
\hline & $\begin{array}{l}\text { Presence of an enabling national policy for impact } \\
\text { investments and SIBs }\end{array}$ & 12 & 2 & 5 & 4.00 & 3.00 & 4.50 & 0.034 & 0.007 & 0.307 & 0.106 & $0.020 * *$ & 0.972 & 0.369 \\
\hline & Presence of guarantees/insurance & 12 & 2 & 5 & 3.50 & 2.50 & 4.00 & 0.182 & 0.005 & 0.000 & 0.078 & 0.248 & 0.178 & 0.766 \\
\hline & $\begin{array}{l}\text { The entire process is constantly monitored and } \\
\text { timely adjusted for any relevant changes }\end{array}$ & 12 & 2 & 5 & 4.00 & 4.00 & 4.50 & 0.230 & 0.009 & 0.036 & 0.110 & $0.005^{* * *}$ & 0.207 & 0.924 \\
\hline & Clear identification of goals and tasks & 12 & 3 & 5 & 4.00 & 4.00 & 4.50 & 0.178 & 0.121 & 0.008 & 0.112 & $0.004 * * *$ & 0.734 & 0.679 \\
\hline & Clear project planning & 12 & 3 & 5 & 4.00 & 4.00 & 4.00 & 0.257 & 0.055 & 0.000 & 0.124 & $0.003 * * *$ & 0.357 & 1.000 \\
\hline \multirow{9}{*}{ RIs } & High transaction costs & 12 & 3 & 5 & 4.00 & 4.00 & 5.00 & 0.369 & 0.000 & 0.000 & 0.112 & $0.004 * * *$ & 0.734 & 0.245 \\
\hline & Absence of cashable savings for the public sector & 12 & 2 & 5 & 4.00 & 2.50 & 4.50 & 0.231 & 0.000 & 0.058 & 0.095 & $0.100^{*}$ & 0.896 & 0.247 \\
\hline & Differences in working method between partners & 12 & 2 & 5 & 3.00 & 3.00 & 3.50 & 0.111 & 0.171 & 0.080 & 0.114 & 0.257 & 0.733 & $0.052^{*}$ \\
\hline & High operational costs & 12 & 2 & 5 & 4.00 & 3.00 & 4.00 & 0.008 & 0.421 & 0.003 & 0.118 & $0.035^{* *}$ & 0.115 & 0.283 \\
\hline & Absence of exit opportunities & 12 & 2 & 5 & 3.50 & 3.00 & 4.00 & 0.040 & 0.330 & 0.044 & 0.120 & 0.107 & 0.081 * & 0.384 \\
\hline & Unstable government & 12 & 1 & 5 & 4.00 & 3.00 & 4.50 & 0.012 & 0.000 & 0.241 & 0.106 & $0.068^{*}$ & 0.972 & 0.703 \\
\hline & Delays in project approvals and permits & 12 & 1 & 5 & 3.50 & 3.00 & 4.50 & 0.124 & 0.003 & 0.158 & 0.105 & 0.140 & 0.880 & 0.853 \\
\hline & Change in law & 12 & 1 & 5 & 3.00 & 3.00 & 4.00 & 0.102 & 0.035 & 0.190 & 0.121 & 0.408 & 0.759 & 0.144 \\
\hline & Lack of commitment of the involved partners & 12 & 2 & 5 & 5.00 & 4.50 & 5.00 & 0.002 & 0.040 & 0.226 & 0.108 & $0.003 * * *$ & 0.048 ** & 0.443 \\
\hline
\end{tabular}


When the comparison was made with respect to the demographic variables, as suggested by $\mathrm{H} 2$, the results were not always concordant. The only exceptions were recorded from the variables "SIBs offer an interesting financial return" ( $p$-value $=0.025)$, "Good track records and the prior experience of all parties involved" ( $p$-value $=0.114$ ), and "SIBs offer diversification opportunities in our broader portfolio of investment/activities" ( $p$-value $=0.103$ ). In all the above cases, the Australian respondents were motivated by financial return more than all others. In this focus area, nonbehavioral differences among the respondents appeared statistically evident by the type of organization.

In the CSF area, all the respondents significantly rejected (at a 1\% significance level) any hypothesis to consider these aspects in optimal terms. In fact, all responses were considered extremely relevant in terms of correctly evaluating SIB success, with the only exception of the variable "Presence of guarantees/insurance" ( $p$-value $=0.248$ and 3.50 of median).

In the RI area, comparing the evaluations between groups of respondents per geographical areas "Absence of exit opportunities" was the only significantly different variable ( $p$-value $=0.081$ ) with a high perception in the United Kingdom and Australia (3.50 and 4.00 of median, respectively) compared with those in other countries (2.00 of median). Among the different organizations involved in the survey, the risk linked to "Differences in working method and knowledge between partners" ( $p$-value $=0.052)$ was significantly evident with the investors being the most afraid (4.50 of median), followed by the evaluators ( 4.00 of median).

\section{Results and Discussion}

The results of the analysis are presented in Table 3 and reveal that the three factors extracted from the data explain $80.722 \%$ of the total variance in the MO area, $82.494 \%$ in the CSF area, and $84.741 \%$ in the RI area. A varimax rotation provided the best-defined factor structure. All items had primary loadings over 0.55 . The factor loading matrix is presented in Table 4.

In the table above, the absolute loadings that are higher than 0.4 are highlighted. This makes the output easier to read by removing the clutter of low correlations. The loadings close to -1 or 1 indicate that the factor strongly influences the variable while conversely, loadings with values close to 0 indicate that the factor has a weak influence on the variable. Some variables have high loadings on multiple factors. Using the rotated factor loadings, the following aspects merged. 
Table 4. Varimax factor loadings.

\begin{tabular}{|c|c|c|c|}
\hline & Factor 1 & Factor 2 & Factor 3 \\
\hline \multicolumn{4}{|l|}{ Motivations } \\
\hline SIBs offer benefit to local communities & 0.96245 & & \\
\hline SIBs offer opportunities to help people in need & 0.91659 & & \\
\hline Opportunities of risk sharing between the different involved parties & 0.85892 & & \\
\hline We have engaged in similar initiatives before & 0.83909 & & \\
\hline SIBs are a philanthropic opportunity & 0.81839 & -0.4028 & \\
\hline SIBs offer an interesting financial return & & 0.97648 & \\
\hline SIBs offer diversification opportunities in our broader portfolio of investment/activities & & 0.83039 & \\
\hline Good track records and the prior experience of all parties involved & 0.42424 & 0.71436 & \\
\hline Presence of tax relief mechanism & & & 0.90639 \\
\hline SIBs provide opportunities to enter new market sectors & & & 0.77822 \\
\hline Reputational return & & & 0.57238 \\
\hline \multicolumn{4}{|l|}{ Critical Success Factors } \\
\hline Clear project planning & 0.895506 & & \\
\hline The entire process is constantly monitored and timely adjusted for any relevant changes & 0.848078 & & \\
\hline Presence of guarantees/insurance & 0.753902 & & \\
\hline Clear identification of goals and tasks & 0.746467 & & 0.508055 \\
\hline Presence of an enabling national policy for impact investments and SIBs & & 0.816511 & \\
\hline Presence of feasible, credible, and clear social needs identification and description & & 0.814015 & \\
\hline Strong commitment of all involved parties & & 0.776885 & \\
\hline Responsibilities and duties are clearly allocated & & & 0.916123 \\
\hline Efficient cooperation between the involved parties & & & 0.797007 \\
\hline \multicolumn{4}{|l|}{ Risks } \\
\hline Unstable government & 0.88353 & & \\
\hline Lack of commitment of the involved partners & 0.855574 & & \\
\hline Change in law & 0.784897 & 0.487674 & \\
\hline Delays in project approvals and permits & 0.713803 & 0.537572 & \\
\hline High transaction costs & & 0.925543 & \\
\hline Absence of cashable savings for the public sector & 0.432417 & 0.733473 & \\
\hline High operational costs & & & 0.932218 \\
\hline Absence of exit opportunities & & & 0.826007 \\
\hline Differences in working method and knowledge between partners & 0.509355 & 0.508368 & 0.595381 \\
\hline
\end{tabular}

${ }^{*}$ Low factor loadings were removed $(<0.4)$. 


\subsection{Motivations}

In the $\mathrm{MO}$ area of focus, three main factors emerged. Based on their composition, these factors can be labeled as "Social and Impact" (Factor 1), "Financial" (Factor 2), and "Business" (Factor 3). In particular, the variables "SIBs offer opportunities to benefit local communities" (0.96245), "SIBs offer opportunities to help people in need" (0.91659), "Opportunities of risk sharing between the different involved parties" (0.85982), "We have engaged in similar initiatives before" (0.83909), and "SIBs are a philanthropic opportunity" (0.81839) had large positive loadings on Factor 1; therefore, this factor described the respondents' alignments with the social and impact purposes of SIBs. In contrast, the variables "SIBs offer an interesting financial return" (0.97648), "SIBs offer diversification opportunities in our broader portfolio of investment/activities" (0.83039), and "Good track records and the prior experience of all parties involved" (0.71436) had large positive loadings on Factor 2; therefore, this factor describes the respondents' interests in the financial opportunities related to SIBs. The variables "Presence of tax relief mechanism" (0.90639), "SIBs provide opportunities to enter into new market sectors" (0.77822), and "Reputational return" (0.57238) had large positive loadings on Factor 3; therefore, this factor describes the respondents' interests in some kind of "business" return related to SIBs. The results of Table 1 provide further interesting insights by considering the variables that have different loadings on multiple factors. In this vein, the variable "SIBs are a philanthropic opportunity" showed a large positive loading (0.81839) on Factor 1 and a negative significant loading $(-0.4028)$ on Factor 2. Variables with negative factor loadings symbolized a negative correlation with their corresponding categories. This aspect can be explained by the fact that the respondents did not perceive SIBs as a philanthropic instrument but, rather, they were more in line with the idea that implementing an SIB, and thus the related innovative social program, may have a positive impact on local communities and, more generally, on society.

Finally, the variable "Good track records and the prior experience of all parties involved" had a large positive loading (0.71436) on Factor 2 and a positive loading (0.42424) on Factor 1 by reflecting the idea that this variable could be considered important to obtaining a positive financial return but also important to obtaining a positive social impact.

\subsection{Critical Success Factors in SIB Projects}

Based on the results shown in Table 4 and considering their composition, the factors are labeled to reflect the characteristics of the variables as "Project Management", "Environment", and "Partnership". As highlighted in Table 4, Factor 1 is composed of the following variables: "Clear project planning" (0.895506), "The entire process is constantly monitored and timely adjusted for any relevant changes" (0.848078), "Presence of guarantees/insurance" (0.753902), and "Clear identification of goals and tasks" (0.746467). Considering the composition, it was labeled "Project Management" as it grouped a series of variables that direct attention towards aspects that, if present in the SIB deal, may lead to a successful project and to the full commitment of the different actors.

The variables "Presence of an enabling national policy for impact investments and SIBs" (0.816511), "Presence of feasible, credible, and clear social needs identification and description" (0.814015), and "Strong commitment of all involved parties" (0.776885) had large positive loadings on Factor 2. Factor 2 was labeled "Environment" because it captured the items creating a favorable environment for project success. Under this factor, both aspects related to the single project (e.g., "Presence of feasible, credible and clear social needs identification and description" and "Strong commitment of all involved parties") and aspects related to a national and policy level (e.g., "Presence of an enabling national policy for impact investments and SIBs") were grouped.

Finally, the variables "Responsibilities and duties are clearly allocated" (0.916123), and "Efficient cooperation between the involved parties" (0.797007), had large positive loadings on Factor 3 . Considering its composition, Factor 3 was labeled "Partnership" since its variables refer to the importance of collaboration of the several involved actors within the project. 


\subsection{Risks in SIB Projects}

Concerning RIs, after the PCA, three main factors were identified: "Political, Regulatory, and Policy Environment", "Project Execution", and "Project Design". The first RI factor refers to the "political, regulatory and policy environment" that brings together all the variables that refer to "macro" issues such as the possibility that new legislation or policies ("Change in law", "Unstable government") would change the composition of the target population or undermine the implementation of the entire project. In more detail, the following variables had large positive loadings on Factor 1-Political, Regulatory, and Policy Environment: "Unstable government" (0.88353), "Lack of commitment of the involved partners" (0.855574), "Change in law" (0.784897), and "Delays in project approvals and permit" (0.713803).

Factor 2 refers to the "project design" that brings together all the items connected to mistakes in the early phase of the project where the project's key features, structure, criteria for success, and major aspects are all planned out. In particular, the variables "High transaction costs" (0.925543), and "Absence of exit opportunities" (0.733473) had large positive loadings on Factor 2-Project Design.

Factor 3 refers to the "project execution" and brings together all the items related to the possibility that projects fail because they are not executed in a manner consistent with what the design and evidence say, often leading to "high operational costs". At the same time, during the project execution, and considering the growth of operational costs, some actors would not be able to exit the deal, and they are thus forced to bear losses. The variables "High operational costs" (0.932218), "Absence of exit opportunities" (0.826007), and "Differences in working method and knowledge between partners" (0.595381) showed large positive loadings on Factor 3 -Project Execution.

The results of Table 4 provide further interesting insights by considering the variables with different loadings on multiple factors. In particular, the variables "Change in law", "Delays in project approvals and permits", and "Absence of cashable savings for the public sector" show positive loadings on both Factor 1-Political, Regulatory, and Policy Environment, and Factor 2-Project Design, while the variable "Differences in working method and knowledge between partners" showed positive loadings on all factors.

These overlaps can be explained by the fact that the same risk factor may arise in different stages of SIB projects and may thus affect the programming stage - in which the public sector, at a political level, decides to begin using this kind of public procurement instrument-or the design and the execution stage. In this sense, the Peterborough SIB can help us to explain the overlap of the variable "Change in law" in both Factor 1 and Factor 2. The Peterborough SIB is well known as the first SIB launched in 2010 in the United Kingdom and as the first SIB that suffered an early termination due to the third cohort cancellation. Usually, policy changes are a foreseen possibility for long-term contracts, and SIB contracts usually include clauses for this eventuality. The Peterborough SIB contract included both "termination for convenience" and "mutual termination" clauses. However, the change in law also caused effects on the structure of the Peterborough SIB due to the cancellation of the third cohort, thus affecting the initial project design and causing difficulties in the final outcome calculation.

Finally, the variable "Differences in working method and knowledge between partners" highlighted the importance of partnership and collaboration in an SIB project with similar positive loading in all three factors (with a slight prevalence in the third factor).

\section{Conclusions, Implications, and Future Research Directions}

This study identified and assessed the various MOs, CSFs, and RIs associated with SIB projects. In doing so, the study adopted a mixed-method grounded theory methodology. The application of principal component analysis was required to reduce the 29 original items to a few more meaningful principal latent components. The analysis focused on the private-sector actors of SIBs to understand why they were interested in participating in such projects and to identify their main perceived success drivers and risk factors. 
The following aspects emerged from the literature review: (1) based on their role (investors, intermediaries, service providers), each actor might have many motivations for engaging in an SIB; and (2) motivations span from philanthropic aims to business opportunities and financial returns.

Regarding MOs, the results of the analysis are not surprising when compared with those of previous studies; however, they lead to a better understanding of the main levers that could be useful for private actors' engagement. Considering the findings, SIBs are positioned between the possibility to obtain a good financial return and the possibility to contribute to the community's well-being. The two main factors emerging from the analysis are "Social and Impact" and "Financial". The analysis appears to be in line with the suggestions of the literature. However, from these two main groups of motivations, which are in line with the impact investing principles, the possibility of obtaining business advantages emerges. In this vein, for example, social enterprises, financial intermediaries, and advisors consider SIBs as a strategy to enter new markets by gaining a competitive advantage with respect to competitors or by gaining, for example, fiscal advantages. In this vein, the implementation of a tax relief mechanism may be a driver for attracting social enterprises or third-sector entities such as private investors.

About CSFs, from the analysis, the first factor grouping highlighted the importance of an environment that can stimulate the birth of an ecosystem and the flourishing of the market. This factor, which was labeled "Environment", was composed of different kinds of items including those related to the national level and those related to a single project. At the national level, the presence of a clear policy towards the implementation of SIBs as a social innovation practice may lead to the creation of an ecosystem with specialized advisors, as in the case of the UK, where both the Cabinet Office and Social Finance were able to support the other involved parties by catalyzing and involving them in a shared vision and a shared goal. At the microlevel, and thus at the single-project level, the enabling environment materializes itself when all involved parties can work together and all of them are focused on a common goal. The factor "Project Management" directed attention towards a series of aspects that, if present in the SIB deal, may lead to a successful project and to the full commitment of the actors involved. Moreover, a clear project design—including task identification and specification—may help avoid misunderstanding, overlapping, and the making of mistakes during the implementation stage. If all these aspects are clear and well specified, each actor will be aware of their roles and responsibilities, and thus information asymmetries or principal-agent problems will be avoided. Based on sound project design principles, tasks, roles, and responsibilities should be clearly designed and assigned to the involved parties. These aspects are particularly important in SIB projects considering the wide range of actors involved.

Finally, risk management is extremely important in achieving overall project goals, and the identification of CSFs represents the starting point for an effective risk management strategy: if CSFs are not well managed, they tend to become risks. Considering the results of the analysis, the factor "Project Management" groups a series of items that are strictly related to the RI factors "Project Design" and "Project Execution". This means that the project design stage of an SIB project may at the same time be considered a critical success factor but also a potential source of risk. Under a risk management perspective, avoiding the manifestation of this risk may lead to a successful project.

The contribution of this work to the SIB knowledge was twofold—-theoretical and practical—as it provided some new clues regarding the main MO, CSF, and RI factors that should be considered for future implementation.

First, this study provides a necessary theoretical grounding to conceptualize some aspects that have been unexplored in the previous works. In this sense, confirmation of findings by two different approaches or methodologies-including qualitative ones-paves the way towards greater completeness, validity, and generalizability. Second, the findings may help practitioners in reviewing the necessary CSFs when considering implementing risk assessment and management practices. 
Furthermore, the identified CSFs could be used as a road map for the successful implementation of risk assessment and management practices. The findings can have an impact on the public and private sectors.

The limitations of this study refer mainly to the sample size. However, a Cronbach's alpha coefficient for the reliability test and the chi-square for validity tests were used and they indicated that the questionnaire was valid and consistent. Furthermore, this study focused on exploring questions that are foundational to understanding SIBs. In doing so, the design of the study was process-rather than variance-focused. The focus was to build a list of CSFs, MOs, and RIs related to why different kinds of actors (service providers, investors, advisors) choose to become involved in SIBs rather than their effective preferences. For these reasons, the preliminary 12 respondents represented the "pilot test" of the lists. Thus, it will be necessary to conduct additional research on more types of CSFs, MOs, and RIs and to continue exploring the possibilities to improve the sample of respondents. Despite its limitations, this present study offers some insights and useful information from both policymakers and private sector providers concerning the important factors that should be emphasized in ensuring the successful implementation of SIBs. The identification of specific MO, CSF, and RI factors in SIB projects will assist the involved stakeholders in focusing their attention, priorities, and risk management practices on managing the identified factors. Additionally, the identified risk factors can be used to develop a risk management framework that is suitable for stakeholders.

Author Contributions: R.C. conceived, designed, implemented, and supervised the research; R.D.L. supervised the research, and gave valuable advice; and F.R. conducted the formal analysis. In greater detail, R.C. contributed to Section 2, Section 2.1, Section 2.2, Section 2.3, Section 2.4, Section 3, Section 5, Section 5.1, Section 5.2, Section 5.3, Section 6; R.D.L. contributed to Section 1; and F.R. contributed to Section 4. All authors have read and agreed to the published version of the manuscript.

Funding: This work was realized in the framework of the Project Social Impact Finance (SIF16_00055) “An Italian platform for impact finance: financial models for social inclusion and sustainable welfare" (in collaboration with Sapienza, University of Rome, Project Leader), funded by the Italian Ministry of the Education, University and Research (MIUR), PNR (2015-2020), DD. 2153, 12.10.2016; DD. 1303, 30.05.2017.

Acknowledgments: The authors would like to express their sincere gratitude for the valuable comments and suggestions received from the interviewed practitioners. The authors would also like to thank the participants of the 3rd Social Impact Investments International Conference (5-6 December 2019, Rome) for their inspiring advice.

Conflicts of Interest: The authors declare no conflict of interest.

\section{References}

1. Broccardo, E.; Mazzuca, M. The missing link? Finance, public services, and co-production: The case of social impact bonds (SIBs). Public Money Manag. 2019, 39, 262-270. [CrossRef]

2. Carè, R.; De Lisa, R. Social Impact Bonds for a Sustainable Welfare State: The Role of Enabling Factors. Sustainability 2019, 11, 2884. [CrossRef]

3. La Torre, M.; Trotta, A.; Chiappini, H.; Rizzello, A. Business Models for Sustainable Finance: The Case Study of Social Impact Bonds. Sustainability 2019, 11, 1887. [CrossRef]

4. Rizzello, A.; Carè, R. Insight into the social impact bond market: An analysis of investors. ACRN Oxf. J. Financ. Risk Perspect. 2016, 5, 145-171.

5. FitzGerald, C.; Fraser, A.; Kimmitt, J. Tackling the Big Questions in Social Impact Bond Research through Comparative Approaches. J. Comp. Policy Anal. Res. Pract. 2020, 1-15. [CrossRef]

6. Rizzello, A.; Caridà, R.; Trotta, A.; Ferraro, G.; Carè, R. The use of payment by results in healthcare: A review and proposal. In Social Impact Investing Beyond the SIB; Palgrave Macmillan: Cham, Switzerland, 2018; pp. 69-113.

7. Rania, F.; Trotta, A.; Carè, R.; Migliazza, M.C.; Kabli, A. Social Uncertainty Evaluation of Social Impact Bonds: A Model and Practical Application. Sustainability 2020, 12, 3854. [CrossRef]

8. Carè, R. Social Impact Bond: Beyond financial innovation. In Sustainable Financial Innovation; CRC Press: Boca Raton, FL, USA, 2019; pp. 149-171.

9. Social Finance. SIB Database. Available online: https://sibdatabase.socialfinance.org.uk (accessed on 26 May 2020). 
10. FitzGerald, C.; Carter, E.; Dixon, R.; Airoldi, M. Walking the contractual tightrope: A transaction cost economics perspective on social impact bonds. Public Money Manag. 2019, 39, 1-10. [CrossRef]

11. Roundy, P.; Holzhauer, H.; Dai, Y. Finance or philanthropy? Exploring the motivations and criteria of impact investors. Soc. Responsib. J. 2017, 13, 491-512. [CrossRef]

12. Schinckus, C. Financial innovation as a potential force for a positive social change: The challenging future of social impact bonds. Res. Int. Bus. Financ. 2017, 39, 727-736. [CrossRef]

13. Pandey, S.; Cordes, J.J.; Pandey, S.K.; Winfrey, W.F. Use of social impact bonds to address social problems: Understanding contractual risks and transaction costs. Nonprofit Manag. Lead. 2018, 28, 511-528. [CrossRef]

14. Scognamiglio, E.; Di Lorenzo, E.; Sibillo, M.; Trotta, A. Social uncertainty evaluation in Social Impact Bonds: Review and framework. Res. Int. Bus. Financ. 2019, 47, 40-56. [CrossRef]

15. Clifford, J.; Jung, T. Social Impact Bonds: Exploring and Understanding an Emerging Funding Approach. In Routledge Handbook of Social and Sustainable Finance; Lehner, O., Ed.; Routledge: London, UK, 2016; pp. 161-176.

16. Nazari Chamaki, F.; Jenkins, G.P.; Hashemi, M. Social Impact Bonds: Implementation, Evaluation, and Monitoring. Int. J. Public Adm. 2019, 42, 289-297. [CrossRef]

17. Edmiston, D.; Nicholls, A. Social Impact Bonds: The role of private capital in outcome-based commissioning. J. Soc. Policy 2018, 47, 57-76. [CrossRef]

18. Fraser, A.; Tan, S.; Lagarde, M.; Mays, N. Narratives of promise, narratives of caution: A review of the literature on Social Impact Bonds. Soc. Policy Adm. 2018, 52, 4-28. [CrossRef]

19. Albertson, K.; Fox, C. The marketisation of rehabilitation: Some economic considerations. Probat. J. 2019, 66, 25-42. [CrossRef]

20. Ormiston, J.; Moran, M.; Castellas, E.I.; Tomkinson, E. Everybody wins? A discourse analysis of competing stakeholder expectations in Social Impact Bonds. Public Money Manag. 2020, 40, 237-246. [CrossRef]

21. Del Giudice, A.; Migliavacca, M. Social impact bonds and institutional investors: An empirical analysis of a complicated relationship. Nonprofit Volunt. Sect. Q. 2019, 48, 50-70. [CrossRef]

22. Gustafsson-Wright, E.; Gardiner, S.; Putcha, V. The Potential and Limitations of Impact Bonds: Lessons from the First Five Years of Experience Worldwide; Global Economy and Development at Brookings: Washington, DC, USA, 2015.

23. Joy, M.; Shields, J. Social impact bonds: The next phase of third sector marketization? Can. J. Nonprofit Soc. Econo. Res. 2013, 4. [CrossRef]

24. Goodall, E. Choosing Social Impact Bonds: A Practitioner's Guide; Bridges Ventures: London, UK, 2014.

25. Maier, F.; Meyer, M. Social Impact Bonds and the perils of aligned interests. Adm. Sci. 2017, 7, 24. [CrossRef]

26. Balboa, C.M. Accountability of environmental impact bonds: The future of global environmental governance? Glob. Environ. Politics 2016, 16, 33-41. [CrossRef]

27. Ravi, S.; Gustafsson-Wright, E.; Sharma, P.; Boggild-Jones, I. The Promise of Impact Investing in India; Brookings India Research Paper No. 062019; Brookings Institution India Center: New Delhi, India, 2019.

28. Emerson, J. Risk, return and impact: Understanding diversification and performance within an impact investing portfolio. Impact Assets 2012, 2, 1-15.

29. Ng, A.; Mirakhor, A.; Ibrahim, M.H. Risk sharing and social impact partnerships. In Social Capital and Risk Sharing; Palgrave Macmillan: New York, NY, USA, 2015; pp. 133-156.

30. TeKolste, R.; Eldridge, M.; Hawkins, R. Managing Investors' Risk in Pay for Success Projects; Urban Institute: Washington, DC, USA, 2016. Available online: http://pfs.urban.org/library/content/managing-investors-riskpay-success-projects (accessed on 25 August 2020).

31. Scognamiglio, E.; Rizzello, A.; Chiappini, H. Social Risk and Financial Returns: Evidences from Social Impact Bonds. In Social Impact Investing Beyond the SIB; Palgrave Macmillan: Cham, Switzerland, 2018; pp. 47-68.

32. Brandstetter, L.; Lehner, O.M. Opening the market for impact investments: The need for adapted portfolio tools. Entrep. Res. J. 2015, 5, 87-107. [CrossRef]

33. Burand, D. Globalizing social finance: How social impact bonds and social impact performance guarantees can scale development. NYUJL Bus. 2012, 9, 447.

34. Brennan, K.; Carriere, B.; Currie, S.; Hui, S.W.; Palameta, B. Social Finance Pilot Projects: Interim Report; Social Research and Demonstration Corporation: Ottawa, ON, Canada, 2018.

35. Giantris, K.; Pinakiewicz, B. Pay for success: Understanding the risk trade-offs. Community Dev. Invest. Rev. 2013, 9, 35-39. 
36. The World Bank. The Global Partnership for Results-Based Approaches. Impact Bonds: Considerations for Investment Returns and Pricing of Outcomes (No. 140224, pp. 1-20). Available online: https://www.gprba.org/sites/gpoba/files/publication/downloads/2019-06/Impact\%20Bonds\%20an d\%20Considerations\%20for\%20Investment-6-25-2019_0.pdf (accessed on 25 August 2020).

37. Jackson, E.T. Evaluating social impact bonds: Questions, challenges, innovations, and possibilities in measuring outcomes in impact investing. Community Dev. 2013, 44, 608-616. [CrossRef]

38. Warner, M.E. Private finance for public goods: Social impact bonds. J. Econ. Policy Reform 2013, 16, 303-319. [CrossRef]

39. Burand, D. New development: The application of incomplete contract theory to documenting Social Impact Bonds. Public Money Manag. 2020, 40, 247-249. [CrossRef]

40. Ford, D.N.; White, R.J., III. Social impact bonds: The goose and the golden eggs at risk. Syst. Res. Behav. Sci. 2020, 37, 333-344. [CrossRef]

41. Bergfeld, N.; Klausner, D.; Samel, M. Improving Social Impact Bonds: Assessing Alternative Financial Models to Scale Pay-for-Success. Annu. Rev. Policy Des. 2019, 7, 1-20.

42. Sekaran, U.; Bougie, R. Research Methods for Business: A skill-Building Approach; Wiley: New Delhi, India, 2010.

43. Glaser, B.; Strauss, A. The Discovery of Grounded Theory; Aldine Press: Chicago, IL, USA, 1967.

44. Strauss, A.; Corbin, J. Basics of Qualitative Research: Grounded Theory Procedures and Techniques; Sage Publications: Newbury Park, CA, USA, 1990.

45. Creswell, J.W. Revisiting mixed methods and advancing scientific practices. In The Oxford Handbook of Multimethod and Mixed Methods Research Inquiry; Hesse-Biber, S., Johnson, R.B., Eds.; Oxford University Press: New York, NY, USA, 2015; pp. 61-71.

46. Morse, J.M. Principles of mixed methods and multimethod research design. Handb. Mix. Methods Soc. Behav. Res. 2003, 1, 189-208.

47. Gideon, L. Handbook of Survey Methodology for the Social Sciences; Springer: New York, NY, USA, 2012.

(C) 2020 by the authors. Licensee MDPI, Basel, Switzerland. This article is an open access article distributed under the terms and conditions of the Creative Commons Attribution (CC BY) license (http://creativecommons.org/licenses/by/4.0/). 